\title{
The appearance of soil-borne viruses in Finnish plant nurseries II
}

\author{
EEVA TAPIO \\ Department of Plant Pathology, University of Helsinki, Finland
}

\begin{abstract}
In the beginning of the 1970's, the occurrence of soil-borne viruses in 30 Finnish nurseries and experimental fields of garden plants at 3 research stations was mapped. Viruses were isolated on $26.9 \%$ of the 672 plant and soil samples collected. The two most commonly found viruses were tobacco necrosis virus (TNV), $42.5 \%$, and tobacco rattle virus (TRV), $23.7 \%$. Tomato black ring virus (TBRV) and raspberry ringspot virus (RRSV) were isolated for the first time in Finland. The abundant occurence of TBRV in 32 samples was due to the abundance of Phlox paniculata samples. RRSV was isolated from only a few samples. The vectors of all of the above-mentioned viruses were found in many samples. The fungus vector of TNV, Olpidium brassicae, was investigated by examining the roots microscopically. The vector of TRV, the Trichodorus sp. nematodes, and the vector of TBRV and RRSV, the Longidorus sp. nematodes, were isolated from soil samples. In addition to the foregoing, tobacco mosaic virus was isolated from 31 samples of 6 nurseries and 2 experimental fields.

Viruses were isolated from many weed samples, especially from roots of Senecio vulgaris and Stellaria media. Perennials proved to be virotic. All of the above mentioned viruses, especially TBRV and TRV, were isolated from Phlox paniculata; TBRV was also found in an Astilbe $x$ arendsii sample. Dicentra spectabilis, like Phlox, was commonly infected with TRV. No clear results could be obtained from control experiments.
\end{abstract}

\section{Introduction}

Until now, only preliminary results have been published of the studies made in the beginning of the 1970's on soil-borne viruses present in Finnish nurseries (TAPIO 1972, 1976). In these, it was found that the fungi-borne tobacco necrosis virus (TNV) and the tobacco rattle virus (TRV) transmitted by Trichodorus-nematodes, were quite widespread in several nurseries. During the years 1971-73, more samples were collected from nearly all of the plant nurseries in Finland, and from some experimental fields. An attempt was also made to find out the effects of fallowing, peat addition, and soil disinfection on the survival of viruses in the soil.

\section{Material and methods}

Sampling

The collecting of samples began in autumn 1970 , and was continued the following au- 


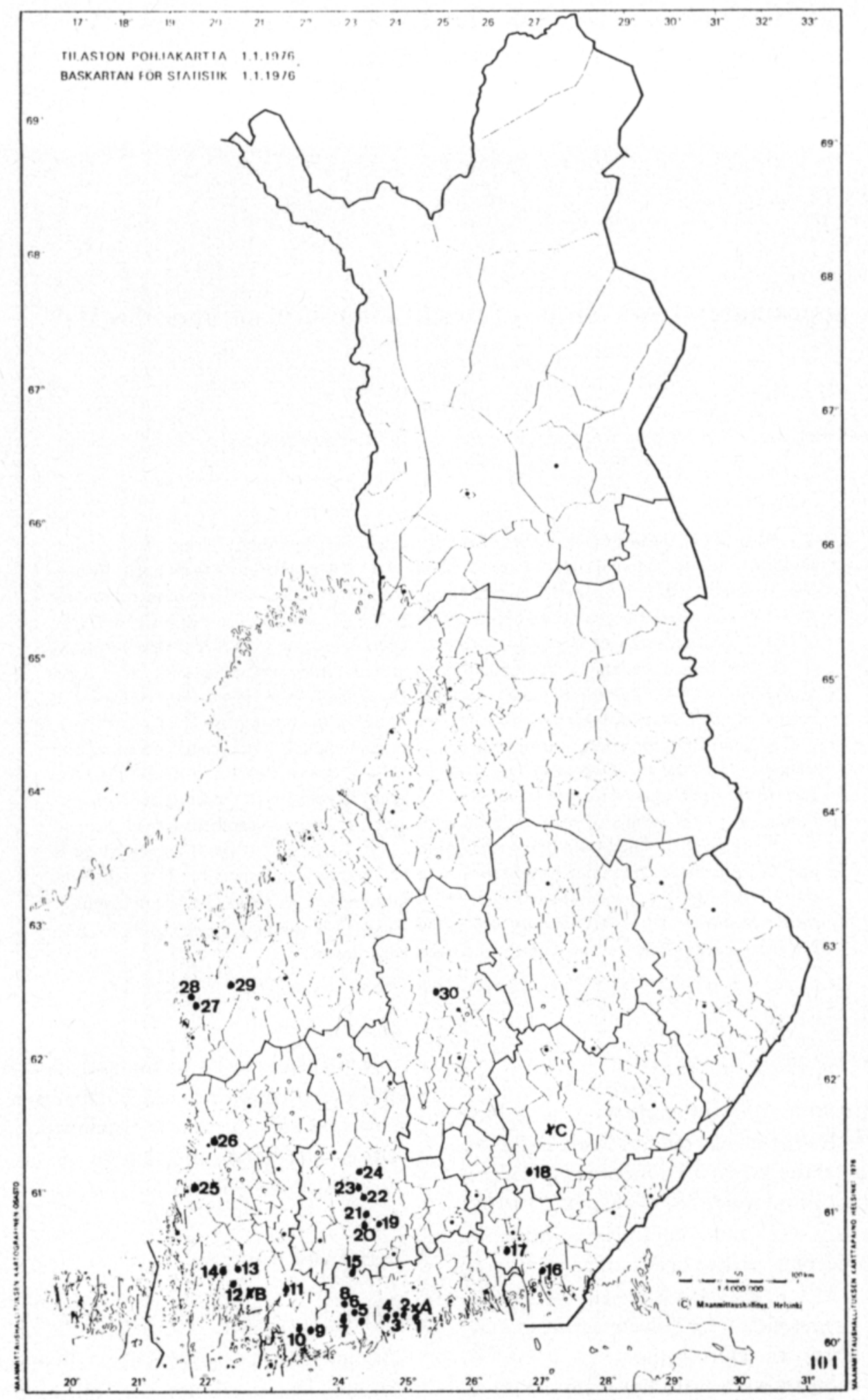

Fig. 1. Map showing the geografical position of investigated nurseries $(\bullet 1-30)$ and experimental fields $(\times \mathrm{A}-\mathrm{C})$. 
Table 1. Viruses and virus vectors in soil and plant samples collected in 1970-1972 from plant schools and experimental fields.

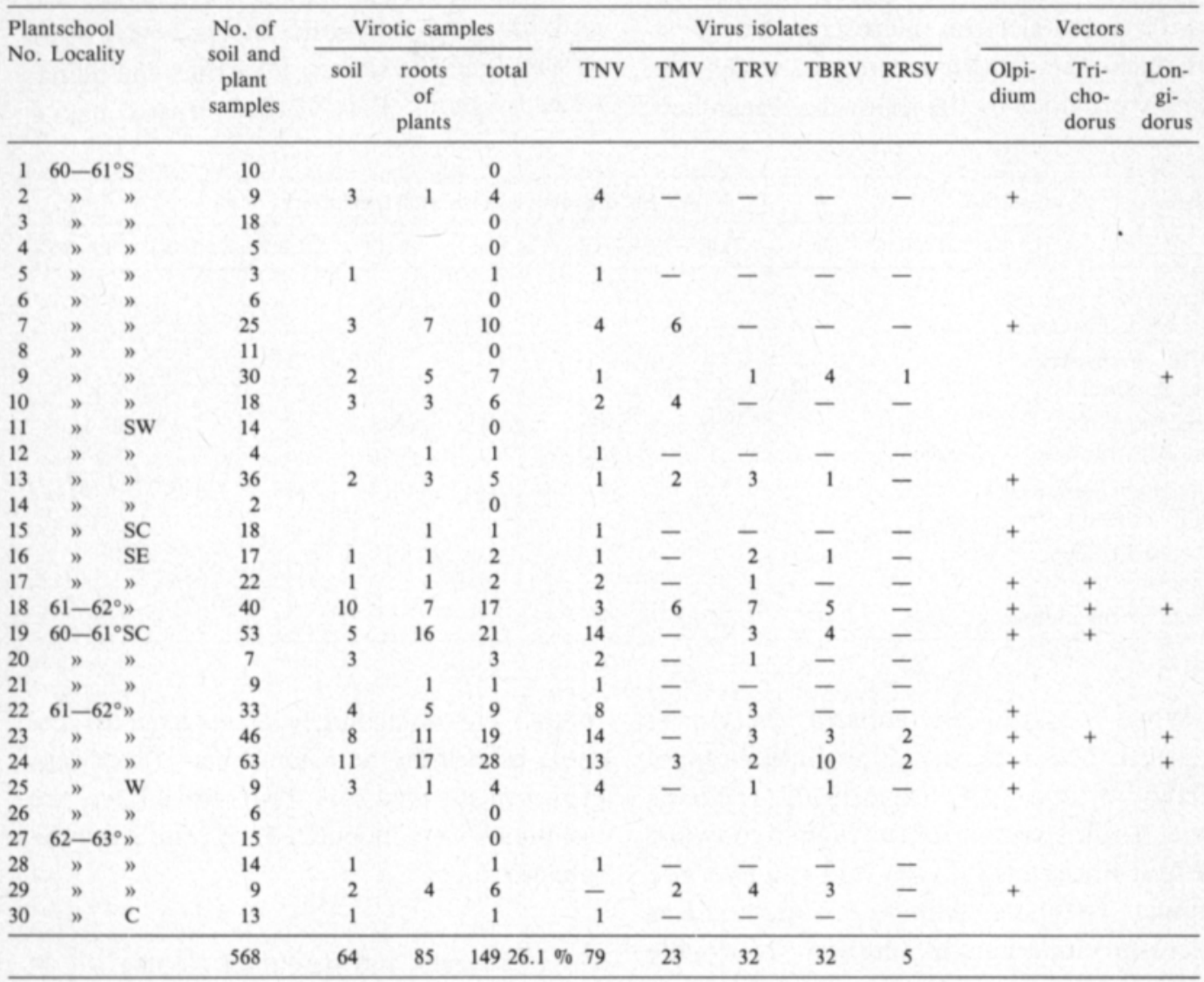

Experimental fields

\begin{tabular}{|c|c|c|c|c|c|c|c|c|c|c|}
\hline A $60-61^{\circ} \mathrm{S}$ & 40 & 10 & 3 & 13 & 4 & & 12 & & + & + \\
\hline B $\Rightarrow \quad$ SW & 39 & 6 & 3 & 9 & 3 & 1 & 5 & & + & + \\
\hline C $61-62^{\circ} \mathrm{SE}$ & 25 & 7 & 3 & 10 & 2 & 7 & & 2 & + & \\
\hline & 104 & 23 & 9 & $\begin{array}{l}32 \\
31 \%\end{array}$ & 9 & 8 & 17 & 2 & & \\
\hline
\end{tabular}

tumn and supplemented to some extent during the following two years. Altogether, soil and plant samples were taken from 30 nurseries and from experimental fields for garden plants at three research stations. (Fig. 1 and Table 1.) The soil samples were drilled mainly from the surface soil layer to a depth of 25 to 30 $\mathrm{cm}$, in some cases deeper, about 10 drillholes/ sample. In addition, samples of weeds and perennial plants were taken.
Virus testing

Testing for viruses was done in the same manner as in the preliminary investigations (TAPIO 1972). Chenopodium quinoa- and Nicotiana tabacum var. Samsun-seedlings were used as test plants in the first phase, and the latter also as a bait plant in testing the soil samples. When the reaction was positive, inoculation were made from these to the in- 
dicator plants presented in Table 2 .

The test results were varified with serological tests and electron microscope. In the serological tests, antisera were used which were kindly provided by the following researchers: periments. The amounts of soil used for soaking were $100 \mathrm{~g}$ or $150 \mathrm{~g}$ for mineral soils, and $200 \mathrm{~g}$ for peat soils. Marja-Leena MAGNUSSON (née SARAKOSKI) identified the nematodes by genus. Part of the extracted nema-

\begin{tabular}{|c|c|c|c|c|c|c|c|c|c|}
\hline \multirow[t]{2}{*}{ The source of antisera } & \multicolumn{9}{|c|}{ AS for different viruses and their titers } \\
\hline & TNV & TRV & TBRV & RRSV & AMV & SLRV & CLRV & TobRSV & TomRSV \\
\hline $\begin{array}{l}\text { Denmark, Lyngby } \\
\text { Dr. M. Christensen }\end{array}$ & $\begin{array}{l}4 \times+ \\
4 \times+\end{array}$ & 64 & & & & & & & \\
\hline $\begin{array}{l}\text { DDR, Aschersleben } \\
\text { Dr. D. Spaar }\end{array}$ & + & + & $\begin{array}{l}+ \\
+\end{array}$ & + & + & + & & & \\
\hline $\begin{array}{l}\text { Scotland, SHRI } \\
\text { Dr. A.F. Murant }\end{array}$ & $\begin{array}{l}1024 \\
2046\end{array}$ & & $\begin{array}{l}256 \\
512\end{array}$ & $\begin{array}{l}2048 \\
1024\end{array}$ & $\begin{array}{l}2048 \\
1024\end{array}$ & $\begin{array}{l}2048 \\
4096\end{array}$ & & & \\
\hline $\begin{array}{l}\text { The Netherlands, IPO } \\
\text { Dr D.Z. Maat }\end{array}$ & 2048 & & 256 & 512 & 2048 & 1024 & 512 & 2048 & 1024 \\
\hline $\begin{array}{l}\text { The Netherlands } \\
\text { Lisse }\end{array}$ & & 1024 & & & & & & & \\
\hline Made by the author & 2048 & 512 & 256 & 256 & & & & & \\
\hline
\end{tabular}

When preparing our antisera, the viruses were purified using the chloroformbuthanol method (STEERE 1956, TAPIO 1972). The basic inoculation program for the rabbits consisted of four injections into the vein and two into muscle. The most common test method was micro-precipitation. In addition, the double agar-gel diffusion method was used for testing spherical viruses.

Electron microscopy was carried out with a Jeol $100 \mathrm{~S}$. The preparates were usually made by dip method, and to a lesser extent by the spraying method, for securing the TMV- and/or TRV-infection. In addition, virotic tissues were fixed, embedded with polymerizing resins and sectioned ultrathin for electron microscopy.

\section{Vector studies}

The Olpidium-investigations were made as in the preliminary studies (TAPIO 1972): examining microscopically, soaking the washed roots 15-20 minutes in water in a Petri dish, and watering seedlings with zoospore suspension, either including TNV-suspension or not.

The nematode samples were extracted with the Seinhorst-method as in the preliminary ex- todes were immediately transferred to the roots of healthy Samsum-tobacco seedlings grown in steamed soil. Two weeks later, the test plants were inoculated with sap from the tobacco roots.

Tests of weeds and perennial plants

In addition to isolating viruses from weed and perennial plant samples, the suspectibility of the most common weeds and some ornamental plants to viruses was tested by inoculating them artificially. The plants, mostly seedlings, were inoculated mechanically and/ or using vectors with a chosen isolate of every investigated virus. After two to three weeks, reinoculations were made from different parts of the experimental plants to indicator plants.

\section{Control trials}

In control experiments, an attempt was made to determine the effects of fallowing, peat addition, (commonly used in nurseries), and chemical disinfection on the occurrence of nematodes and viruses. In the experimental plots, the nematode populations were small and unevenly distributed. 
One trial was organized in plant nursery no. 24 at Pälkäne, where Longidorus-nematode was isolated from soil samples and tomato black ring virus (TBRV) from 7 of 22 Phlox paniculata-varieties. The soil quality was uneven, varying from predominantly clay-silt to predominantly sand. The nematodes occurred most densely in a spherical area in the middle of the experimental area. The size of the experimental plots was $4 \times 8 \mathrm{~m}$. In experiment A, there were only two replicates, while in experiment B, there were three. The latter was on a block fallowed for one year beforehand, and situated next to A. In autumn of the first year of the experiment, a $4 \mathrm{~m}$ wide strip $2 \mathrm{~m}$ from the end of each experimental plot was separated from the middle of experiment area $\mathrm{A}$ and harrowed thoroughly. Di-Trapex (dichlorpropan-dichlorprop + methylisothiosyanat) was injected $(500 \mathrm{l} / \mathrm{ha})$ by the supplier company (HUHTAMÄKI/FINCOS) on the 20th September in 1973. The soil temperature was $+8.3^{\circ} \mathrm{C}$. The treated soil was rolled. Soil and plant samples were taken from all of the plots four times in summer 1983, and the following year in June and September, to test nematodes and viruses. From each plot, 49 samples were taken, first removing $5 \mathrm{~cm}$ of the surface soil with a drill $2.5 \mathrm{~cm}$ in diameter and $25 \mathrm{~cm}$ in depth. The drill was cleaned with water and alcohol after being used on each plot. The results are shown with the equivalent number of extracted nematodes per $200 \mathrm{~g}$ of soil.

A similar experiment was set up on the sandy experimental ground of the Agricultural Research Center at Tikkurila, where Trichodorus-nematode and tobacco rattle virus (TRV) had been found. The size of the plots was $2 \times 4 \mathrm{~m}$ and there were three replicates. In the first year of the trial, the effects of fallowing and peat addition on the incidence of nematodes and TRV was comparad using a plant stand consisting of perennials such as Anemone, Liatris, Delphinium, Viola, as well as certain ornamental shrubs. The experiment area was expanded the next year by mixing granulated Nemagon (1, 2-dibromi-3-chlorpropan) $700 \mathrm{~kg} / \mathrm{ha}$ into half of the new plots on the 20th of May, 1974. The test plant potato cv. Sieglind was planted two weeks after

Table 2. The reaction of test plants infected with isolated viruses and some of their characteristics.

\begin{tabular}{|c|c|c|c|c|c|c|c|c|c|c|}
\hline \multirow{3}{*}{$\begin{array}{l}\text { Test plant } \\
\text { Chenopodium amaranti- } \\
\text { color C.\&R. }\end{array}$} & \multicolumn{10}{|c|}{$\begin{array}{l}\text { Viruses } / \text { number of isolates tested } \\
\text { Symptoms in test plants }+\mathrm{L}=\text { local lesions }^{1},+\mathrm{S}=\text { systemic }^{1}\end{array}$} \\
\hline & \multicolumn{2}{|c|}{$\mathrm{TNV} / 5$} & \multicolumn{2}{|c|}{$\mathrm{TMV} / 3$} & \multicolumn{2}{|c|}{ TRV $/ 5$} & \multicolumn{2}{|c|}{ TBRV $/ 2$} & \multicolumn{2}{|c|}{ RRSV/1 } \\
\hline & $+\mathrm{L}$ & - & $+\mathrm{L}$ & $\pm \mathrm{S}$ & $\begin{array}{c}+\dot{\mathrm{L}} \\
\text { (irreg.) }\end{array}$ & - & $+\mathrm{L}$ & $+\mathrm{S}$ & $+\mathrm{L}$ & - \\
\hline C. quinoa Willd. & $+\mathrm{L}$ & - & $+\mathrm{L}$ & $\pm \mathrm{S}$ & $+\mathrm{L}$ & - & $+\mathrm{L}$ & $+\mathrm{S}$ & $+\mathrm{L}$ & $+\mathrm{S}$ \\
\hline Nicotiana glutinosa $\mathrm{L}$. & $\pm \mathrm{L}$ & - & $+\mathrm{L}$ & - & $+\mathrm{L}$ & $\pm S$ & - & - & - & - \\
\hline $\begin{array}{l}\text { N. tabacum L. } \\
\text { cv. Samsun } \\
\text { cv. White Burley }\end{array}$ & $+\mathrm{L}$ & - & $\pm \mathrm{L}$ & $+\mathrm{S}$ & $+\mathrm{L}$ & $+\mathrm{S}$ & $\begin{array}{l} \pm \mathrm{L} \\
+\mathrm{L}\end{array}$ & $\begin{array}{l} \pm S \\
+S\end{array}$ & $+\mathrm{L}$ & $+\mathrm{S}$ \\
\hline Petunia hybrida $\mathrm{L}$. & $\pm \mathrm{L}$ & - & $\pm \mathrm{L}$ & $\pm \mathrm{S}$ & $\pm \mathrm{L}$ & $\pm S$ & $+\mathrm{L}$ & $+\mathrm{S}$ & $+\mathrm{L}$ & $+\mathrm{S}$ \\
\hline Phaseolus vulgaris L. & $+\mathrm{L}$ & - & $\pm \mathbf{L}$ & - & $\pm \mathrm{L}$ & & $\pm \mathrm{L}$ & $\pm \mathrm{S}$ & $\pm \mathrm{L}$ & $\pm \mathrm{S}$ \\
\hline Tetragonia expansa $\mathrm{L}$. & $+\mathrm{L}$ & - & $+\mathrm{L}$ & $+\mathrm{S}$ & $\pm \mathrm{L}$ & $\pm S$ & & & & \\
\hline
\end{tabular}

$1 \pm \mathrm{L}$ and $\pm \mathrm{S}$ reaction variable with isolates, - no reaction

Size of the particles, $\mathrm{nm}$

ca. 26

Thermal inactivation point

Stability in vitro weeks

Dilution end point
300

$$
\begin{array}{r}
180-200 \times 22 \\
40-120 \times 22
\end{array}
$$

30

$$
\begin{array}{cc}
60-65^{\circ} \mathrm{C} & 65-70^{\circ} \mathrm{C} \\
2-3 & 2-3 \\
10^{-3}-10^{-4} & 10^{-3}-10^{-4}
\end{array}
$$


the treatment. The samples were taken the same way as in the previously described experiment.

In both experimental areas, Tagetes erecta L. was planted on $2 \mathrm{~m}^{2}$ plots, because the excretion of the roots of this plant is found to have nematicidal effect (OOESTENBRINK et al. 1957 and Uhlen-Broek and Bijloo 1958).

\section{Results}

The occurrence of viruses and vectors in nurseries and experimental fields

On the 30 investigated nurseries (Fig. 1.), 21 , or $70 \%$, were found to have soil-borne viruses. Viruses were isolated in 149, or $26.2 \%$, of the 568 plant and soil samples (Table 1). Of the 104 soil and plant samples collected at the three experimental fields of garden plants, 32 , or $31 \%$, were found to contain viruses.

Almost half, $42.5 \%$, of all virus isolated were of tobacco necrosis virus, TNV, which was present in nearly all nurseries. The vector in TNV, Olpidium brassicae, was found in the samples of 12 nurseries by examining microscopically either the roots of sample plants, or the roots of tobacco or lettuce which were grown as bait plants on soil samples. However, not all of the samples were investigated methodically in this respect.

Tobacco mosaic virus, TMV, was found in 31 samples, which were from six nurseries and two experimental fields. One rather small nursery, no. 7, was so heavily infected with TMV that the grower found it difficult to grow healthy plants without the yearly addition of peatcover.

Tobacco rattle virus, TRV was isolated from 49 samples of 13 nurseries and two experimental fields. Trichodorus-nematode was soaked from two soil samples of each four nurseries and two experimental fields, the amount of nematodes varying from 10 to 49 in $100 \mathrm{~g}$ soil.

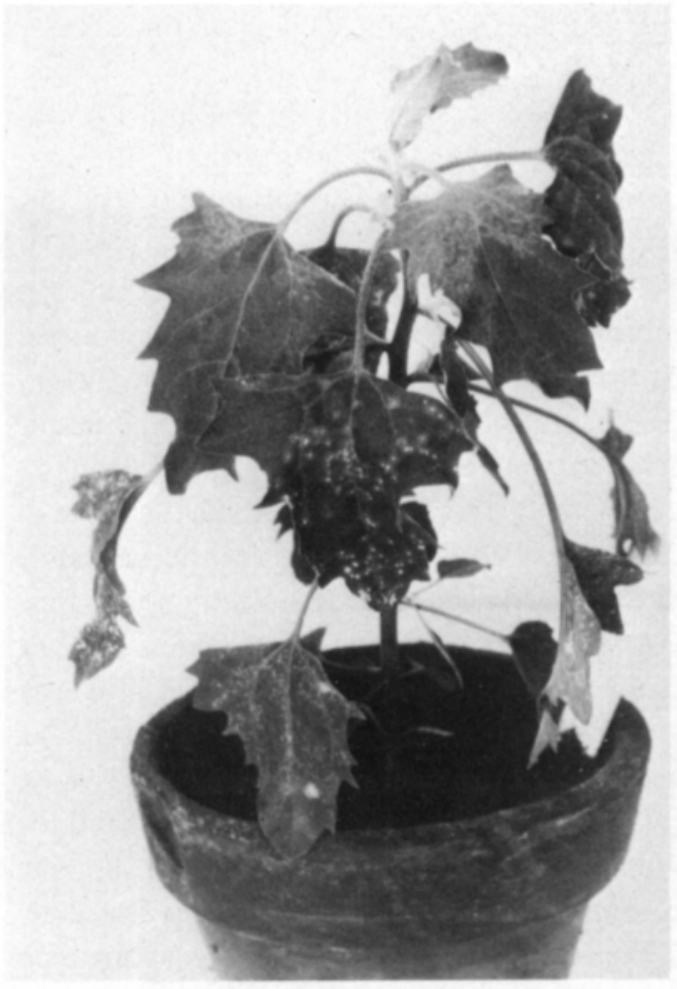

Fig. 2. Tomato black ring virus. Local lesions and systemic symptoms in Chenopodium quinoa.

Tomato black ring virus, TBRV, was found commonly in 32 samples of 9 nurseries. TBRV was most often isolated from the roots of Phlox paniculata or from weeds at the site, or from the soil. Longidorus-nematode was soaked from the soil samples collected on four sampling sites, the amount varying from 11 to 35 in $100 \mathrm{~g}$ soil.

Raspberry ring spot virus, RRSV, was isolated from the roots of Senecio vulgaris once, from Phlox paniculata twice, and from Ribes rubrum cv. Rondom once.

TNV, TMV and TRV were isolated equally from both plant and soil samples, while TBRV and RRSV were isolated almost exlusively from the roots of perennial plants.

\section{Isolated viruses}

Altogether, 207 virus isolates were made (Table 1). A summary of the local (L) and 
systemic (S) symptoms of the various viruses on the most important test plants is presented in Table 2. When symptoms were unclear, inoculations back to sensitive test plants exhibiting distinct reactions were made from experimental plants, in order to detect latent infections. In most cases the results were checked serologically, or by electron microscope.

TNV- and TRV-isolates were similar to those described earlier (TAPIO 1972), that is some test plants, especially Nicotiana-species and Phaseolus vulgaris, reacted to some extent in a variable manner when inoculated with isolates. The determination of TNV was confirmed serologically, primarily by using a selfmade mixture of antisera of serotypes A and D. (cf. TAPIO 1972). Comparative tests were also made with other antisera.

Aside from the use of test plants and serological reactions, the determination of TRVisolates was confirmed most often with electron microscope. The determination of TMV did not cause problems.

Tomato black ring virus, TBRV and raspberry ring spot virus, RRSV were first identified with Chenopodium-species. The former caused systemic symptoms on both $C$. quinoa and $C$. amaranticolor, the latter only on $C$. quinoa (Fig. 2). Petunia reacted variably, only seldom with clear ring spot symptoms (Fig. 3 and 4). The determination of TBRV and RRSV was always confirmed serologically. In the material treated here, there was no arabis mosaic virus, AMV, which was later found in rhubarb (TAPIO unpublished).

Thermal end points varied considerably, especially in TNV-, TMV- and TRV-isolates. Stability in vitro and dilution end point were normal for the viruses (Table 2). Other detailed studies with different isolates could not be made because the author moved, while the handling of the material was unfinished, from the Agricultural Research Center to the Department of Plant Pathology of Helsinki University, which at that time had no virus research equipment.

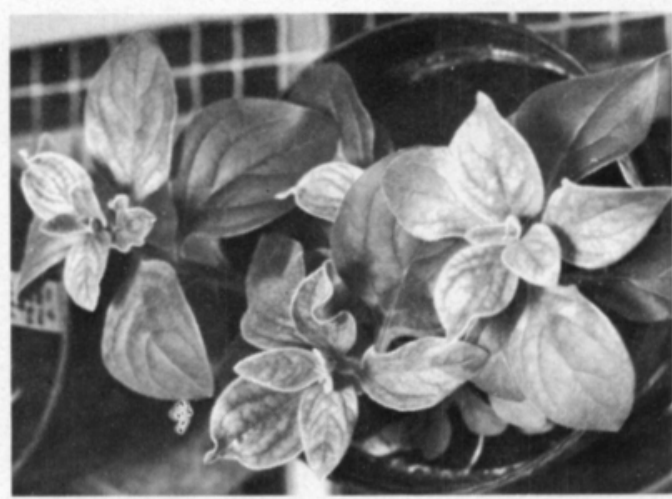

Fig. 3. Tomato black ring virus. Systemic interveinal chlorosis in Petunia hybrida.

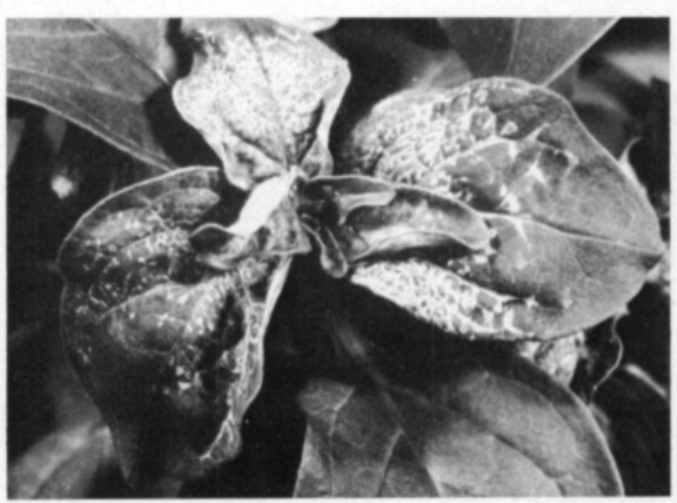

Fig. 4. Raspberry ring spot virus. Systemic ring-spotting in Petunia hybrida.

The effect of soil type on the occurrence of different virus species

Fine sand and silt were the most common soil types in different plant nurseries (Fig. 5). About one fifth of the samples were soils which were primarily or solely organic matter. Clay soils were also fairly common, but sand was rare.

Viruses were isolated from $28 \%$ of the mineral soil samples and about half of the peat and mull samples. TNV, the one that appeared most commonly, was most often found in fine sand and peat soils, TMV in clay and mull soils. Among the nematode-transmitted viruses, TRV was most common in sand and fine sand soils, and TBRV on silt soils, and on soils lighter than silt. 
Susceptibility of weeds and some ornamental plants

Soil-borne viruses were isolated from half of the samples of 16 weed species (Table 3). Senecio vulgaris and Stellaria media were the most common virotic weeds. In infection experiments, all the studied 22 weed species proved to be susceptible to two or more of the viruses tested, either with clear symptoms or latent infection wich was confirmed with back inoculation to indicator plants (Table 4).

The examined TNV-, TMV-, TRV-, TBRVand RRSV-isolates infected the following weed species that commonly occur in nurseries, either by mechanical inoculation or through infection by soil-borne vectors: Achillea millefolium, Capsella bursa-pastoris, Lamium hybridum, L.purpureum, Ranunculus acris, Rumex acetosella, R.crispus, Senecio vulgaris, Stellaria media (Fig. 6), Tripleurospermum maritinum and Viola arvensis. Ranunculus repens was found to be infected with all but TMV, and Urtica urens with all but RRSV. The other test subjects shown in table 4 were less susceptible than the abovementioned species.

One third of 101 Phlox paniculata-samples was found virotic (Table 3). The Phlox material of the nurseries in Finland is badly infected with viruses, especially with TBRV (Fig. 7), but also with TRV, TNV and RRSV. Dicentra spectabilis was commonly infected with TRV. This virus was isolated from all eight D.spectabilis-examples collected from seven plant shops. Furthermore, it is susceptible to TMV (Table 5). From the Astilbe hybrida-sample, TBRV and TNV were isolated.

Susceptibility tests were made for some ornamental plants (table 5). Because there were difficulties in obtaining suitable experimental plants, sample plants with naturally-occuring viral infection have also been shown in the table. Where infection was found in the roots

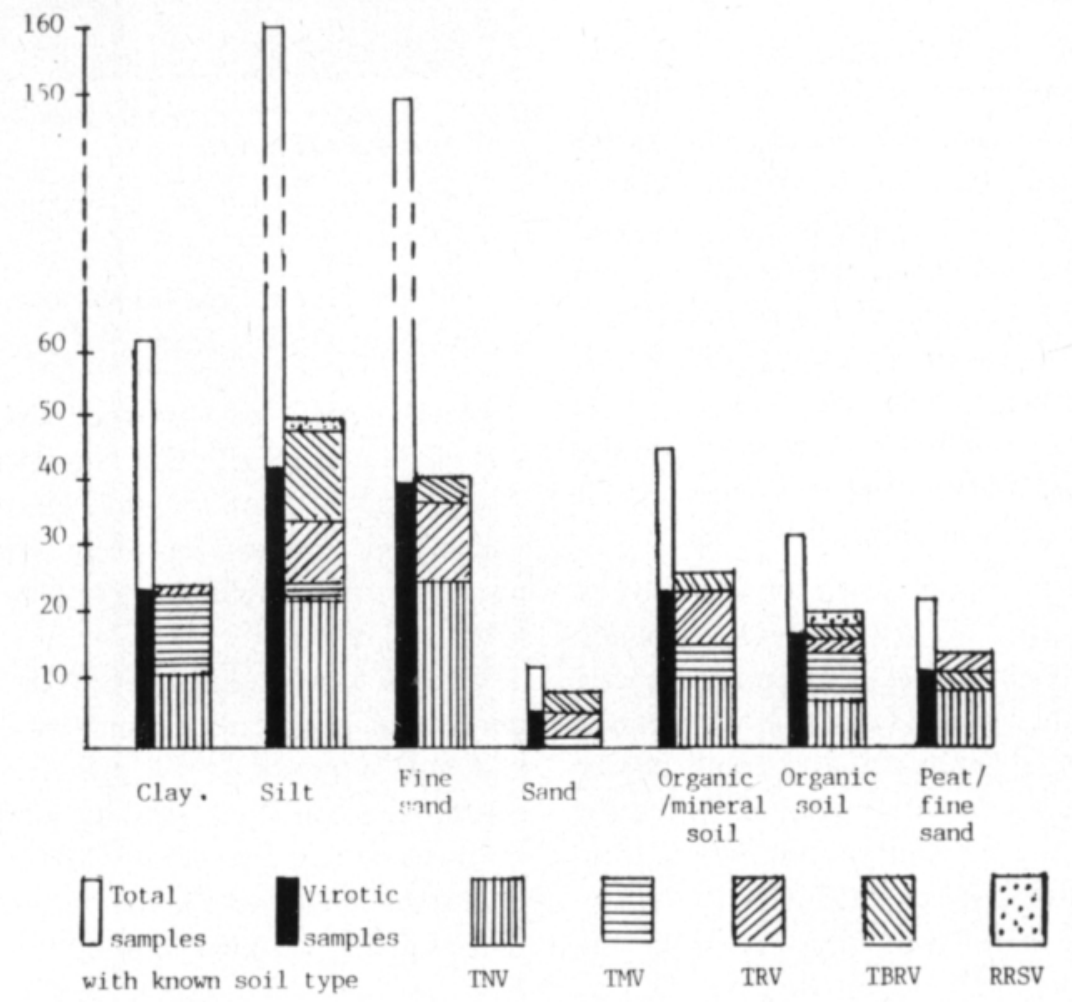

Fig 5. Occurrence of viruses in different soil types in 1970-1972. 
of such plants, it is indicated in the tables by the annotated letter "'R".

Tagetes erecta, which exhibits clear symptoms with TNV, TMV, and TRV, was used as a test plant for annuals as well as perennials. All the above-mentioned viruses were also isolated from the roots of Tagetes. TRV and TBRV on the other hand, could not be isolated from the roots of Tagetes growing in the experimental areas.

\section{Control experiments}

The small-scale experiments, in which an effort was made to determine the effects of fallowing, peat addition and chemical disinfection of soil on the persistence of nematodes and viruses in the soil, did not lead to any clear

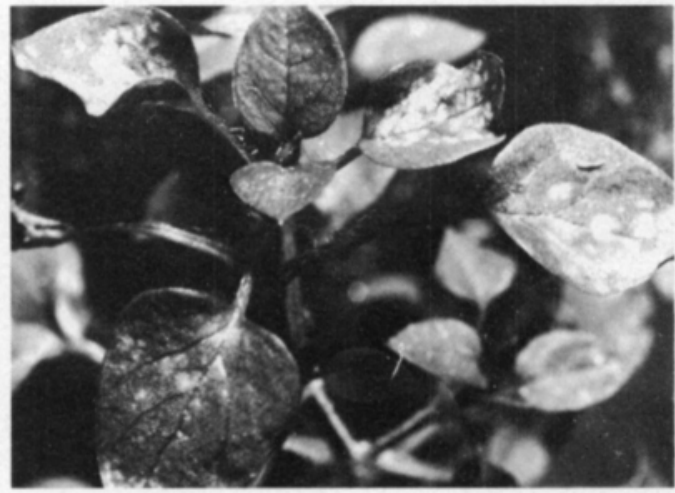

Fig. 6. Tobacco necrosis virus. Local lesions in Stellaria media.

results. In the beginning of the experiment the nematodes were spread unevenly through the experimental area. Longidorus-nematodes

Table 3. Occurrence of viruses in roots of different plant samples in 1970-1972.

\begin{tabular}{|c|c|c|c|c|c|c|c|}
\hline \multirow{3}{*}{$\begin{array}{l}\text { Plant samples } \\
\text { samples } \\
\text { collected }\end{array}$} & \multirow{3}{*}{$\begin{array}{c}\text { No. of plant } \\
\text { samples } \\
\text { collected } \\
\text { Total }\end{array}$} & \multirow{3}{*}{$\begin{array}{l}\text { No. of virotic } \\
\text { plant } \\
\text { samples } \\
\text { Total }\end{array}$} & \multicolumn{5}{|c|}{ Plant samples with viruses } \\
\hline & & & \multirow[t]{2}{*}{ TNV } & \multirow[t]{2}{*}{ TMV } & \multirow[t]{2}{*}{ TRV } & \multirow[t]{2}{*}{ TBRV } & \multirow[t]{2}{*}{ RRSV } \\
\hline & & & & & & & \\
\hline Weeds: & & & & & & & \\
\hline Brassica rapa L. & 1 & 0 & & & & & \\
\hline Capsella bursa-pastoris & & & & & & & \\
\hline (L.) Med. & 3 & 0 & & & & & \\
\hline Centaurea cyanus $\mathbf{L}$. & 1 & 0 & & & & & \\
\hline Chenopodium album $\mathrm{L}$. & 2 & 0 & & & & & \\
\hline Elymus repens (L.) Gould. & 2 & 0 & & & & & \\
\hline Lamium sp. L. & 5 & 2 & 1 & 1 & - & - & - \\
\hline Matricaria inodora $\mathrm{L}$. & 2 & 0 & & & & & \\
\hline Plantago major $\mathrm{L}$. & 1 & 1 & - & 1 & - & - & - \\
\hline Rorippa palustris (L.) Besser & 4 & 1 & - & 1 & - & - & - \\
\hline Rumex acetosella $\mathrm{L}$. & 1 & 1 & - & & - & 1 & - \\
\hline Senecio vulgaris L. & 45 & 15 & 11 & 1 & 1 & 1 & 1 \\
\hline Sonchus arvensis $\mathrm{L}$. & 2 & 0 & & & & & \\
\hline Spergula arvensis L. & 1 & 0 & & & & & \\
\hline Stellaria media (L.) Vill. & 133 & 14 & 8 & 3 & 4 & 2 & - \\
\hline Taraxacum officinales Web. & 48 & 5 & 3 & - & 1 & 1 & - \\
\hline Urtica urens L. & 2 & 0 & & & & & \\
\hline Viola arvensis Murray & 21 & 6 & 5 & 1 & - & - & - \\
\hline \multicolumn{8}{|l|}{ Perennial plants: } \\
\hline Astilbe hybrida & 1 & 1 & - & - & - & 1 & - \\
\hline Crocus vernus $\mathrm{L}$. & 1 & 1 & - & - & 1 & - & - \\
\hline Dicentra spectabilis (L.) Lem. & $1(+8)^{1}$ & $1(+8)^{1}$ & - & - & $1(8)^{1}$ & - & - \\
\hline Phlox paniculata $\mathrm{L}$. & 101 & 34 & 10 & 1 & 10 & 21 & 2 \\
\hline Viola cornuta $\mathrm{L}$. & 4 & 0 & & & & & \\
\hline $\begin{array}{l}\text { Total number of samples } \\
\% \text { of virotic samples }\end{array}$ & 382 & 82 & 38 & 9 & 18 & 27 & 3 \\
\hline$\%$ of virotic samples & & 21.5 & & & & & \\
\hline$\%$ of virotic isolates & & & 40.0 & 9.5 & 18.9 & 28.4 & 3.2 \\
\hline
\end{tabular}

\footnotetext{
1 Collected in 1973
} 
were concentrated in a circular area, their number varying from 0 to $46 / 200 \mathrm{gr}$ soil, in different plots. Trichodorus-nematodes were present in the whole experimental area, although their number varied from 18 to $84 / 200$ $\mathrm{g}$ soil in different plots. The perennial weeds Aegopodium podagraria L. at Pälkäne and Elymus repens $\mathrm{L}$. at Tikkurila made the weeding of fallow plots difficult.

Longidorus-nematodes could not be found at all by soaking from the plots after fallows lasting two or one and a half growing seasons. They were, however, found in weedy plots after a fallow lasting one growing season. Nematodes could not be found in soil that had been treated with Di-Trapex (Table 6). In other plots, however, so few nematodes were found, in some replicates that the differences were not significant in all soakings. Both TBRV and TNV viruses were isolated with bait plants from all the plots except those with a 3-year fallow at the end of the experiment.

Fallowing and peat addition diminished to some extent, but not significantly, the amount of Trichodorus-nematodes. The effect of Nemagon-treatment was not significant, the number of nematodes being small in all the plots at the end of the experiment. TRV could be isolated with bait plants only from stand plots.

Table 4. Reaction of weeds inoculated with Finnish type isolates or naturally infected of soil-borne viruses.

\begin{tabular}{|c|c|c|c|c|c|c|c|c|}
\hline \multirow[t]{3}{*}{ Plant species } & \multicolumn{8}{|c|}{ Reaction ${ }^{\mathrm{T}}$ of weeds infected by } \\
\hline & \multicolumn{2}{|c|}{ TNV } & \multirow{2}{*}{$\begin{array}{l}\text { TMV } \\
\text { mechan. }\end{array}$} & \multicolumn{2}{|c|}{ TRV } & \multicolumn{2}{|c|}{ TBRV } & \multirow{2}{*}{$\begin{array}{l}\text { RRSV } \\
\text { mechan }\end{array}$} \\
\hline & mechan. & Olpid. & & mechan. & Trichod. & mechan. & Longid. & \\
\hline Achillea millefolium $\mathrm{L}$. & --- & S R & $\mathrm{L}--$ & L S R & -- & $\mathrm{L}--$ & & L S R \\
\hline \multicolumn{8}{|l|}{ Capsella bursa-pastoris } & \\
\hline (L.) Med. & --- & $-\mathrm{R}$ & $\mathrm{L}--$ & L S & S R & L S R & S R & L S R \\
\hline Chenopodium album $\mathrm{L}$. & $\mathrm{L}--$ & $-\mathrm{R}$ & --- & $L--$ & $-\mathbf{R}$ & --- & & \\
\hline Epilobium montanum L. & & S R & & $\mathbf{L}-\mathbf{R}$ & & & & \\
\hline Erysimum cheiranthioides L. & --- & -- & L SN R & L S - & S R & --- & - - & -- \\
\hline Galium spurium L. & $\mathrm{L}--$ & $\begin{array}{l}S R \\
-R\end{array}$ & L S R & L S R & S R & L S R & $-\mathbf{R}$ & L S R \\
\hline L. purpureum L. & $\mathrm{L}--$ & $-\mathrm{R}$ & L S R & L S R & S R & L S R & $-\mathbf{R}$ & L S R \\
\hline Lapsana communis $\mathbf{L}$. & --- & & & $\mathrm{L}--$ & -- & & & \\
\hline Matricaria inodora $\mathrm{L}$. & --- & & & & $-\mathbf{R}^{3}$ & & & \\
\hline Myosotis arvensis (L.) Hill. & --- & & & & $-\mathbf{R}^{3}$ & & & \\
\hline Plantago major $\mathrm{L}$. & & $\mathbf{R}$ & $\mathbf{R}^{2}$ & & $\mathrm{R}^{3}$ & & & \\
\hline Polygonum convolvulus L. & $\mathrm{L}--$ & -- & & $-\mathrm{S}$ & S R & & $\mathbf{R}$ & \\
\hline Ranunculus acris L. & $L--$ & -- & L S & & $\mathbf{R}^{3}$ & --- & $-\mathbf{R}$ & \\
\hline R. repens $\mathrm{L}$. & --- & $-\mathrm{R}$ & --- & L S - & -- & L S R & & $\mathbf{L}-\mathbf{R}$ \\
\hline Raphanus raphanistrum $\mathrm{L}$. & --- & $-\mathbf{R}$ & --- & L S - & $\mathbf{R}^{3}$ & & & \\
\hline \multicolumn{9}{|l|}{ Rorippa palustris (L.) Bass. } \\
\hline Rumex acetosella $\mathrm{L}$. & $\mathrm{L}--$ & $-\mathbf{R}$ & --- & $\mathrm{L}--$ & $\mathrm{R}^{3}$ & L S - & & $\mathbf{L}-\mathbf{R}$ \\
\hline R. crispus $\mathrm{L}$. & $\mathrm{L}--$ & $\mathbf{R}$ & $\mathbf{L}-\mathbf{R}$ & L S - & -- & L S R & & $\mathrm{L}-$ \\
\hline Senecio vulgaris $\mathrm{L}$. & --- & $-\mathbf{R}$ & $\mathrm{L}--$ & L S & $-\mathbf{R}$ & L S R & & L S R \\
\hline Sonchus arvensis $\mathrm{L}$. & & $\mathbf{R}$ & & --- & S R & --- & -- & \\
\hline Spergula arvensis $\mathrm{L}$. & $-(\mathrm{S}) \mathrm{R}$ & $-\mathrm{R}$ & $-(\mathrm{S})-$ & --- & $\mathbf{R}$ & --- & $\mathbf{R}$ & --- \\
\hline Stellaria media (L.) Vill. & $\mathrm{L}--$ & $-\mathbf{R}$ & $\mathrm{L}--$ & L S R & S R & L S R & & L S \\
\hline Taraxacum officinale Web. & & $-\mathrm{R}$ & & & $\mathbf{R}$ & & $\mathbf{R}$ & \\
\hline Thlaspi arvense $\mathrm{L}$. & & -- & & & $-\mathbf{R}$ & & & \\
\hline \multicolumn{9}{|l|}{ Tripleurospermum inodorum } \\
\hline Sch.Bip. & $\mathrm{L}--$ & -- & $\mathrm{L}--$ & L S R & $\mathbf{R}$ & L S & & L S R \\
\hline Urtica dioeca $\mathrm{L}$. & --- & $-\mathbf{R}$ & --- & --- & -- & -- & & $--\mathbf{R}$ \\
\hline$U$. urens $\mathrm{L}$. & --- & $\mathbf{R}$ & L S & L S - & $\mathbf{R}$ & L S - & & --- \\
\hline Viola arvensis Murr. & --- & $\mathbf{R}$ & L S R & L $\quad \mathbf{R}$ & $\mathbf{R}$ & L S R & & --- \\
\hline
\end{tabular}

${ }^{1} \mathrm{~L}=$ local lesions, $\mathrm{S}=$ sprouts systemic infected, $\mathrm{R}=$ roots infected, $-=$ no infection

2 weeds grown on TMV infested soil, not mechanically inoculated

${ }^{3}$ weeds grown on nematode and virus infested soil, not inoculated 
The influence of weather on the occurrence of nematodes appeared to be more distinct than that of different treatments. Summer 1973 was dry, and the number of nematodes clearly diminished in the surface layers of the soil temporarily until the autumn rains (Table 7).

\section{Discussion}

Soil-borne viruses were found in $70 \%$ of the nurseries in Finland. From the 568 plant and soil samples collected at 31 nurseries, viruses were isolated from $26.1 \%$. The most commonly found virus isolates were tobacco necrosis virus, $42.5 \%$, and tobacco rattle virus, $23.7 \%$. They are found in almost the same proportions as in Swedish nurseries, according to RYDÉN and ERIKSSON (1978).

The vector of TNV, Olpidium brassicae, was found in the samples of 12 nurseries. The occurrence of fungi in all samples was, how-

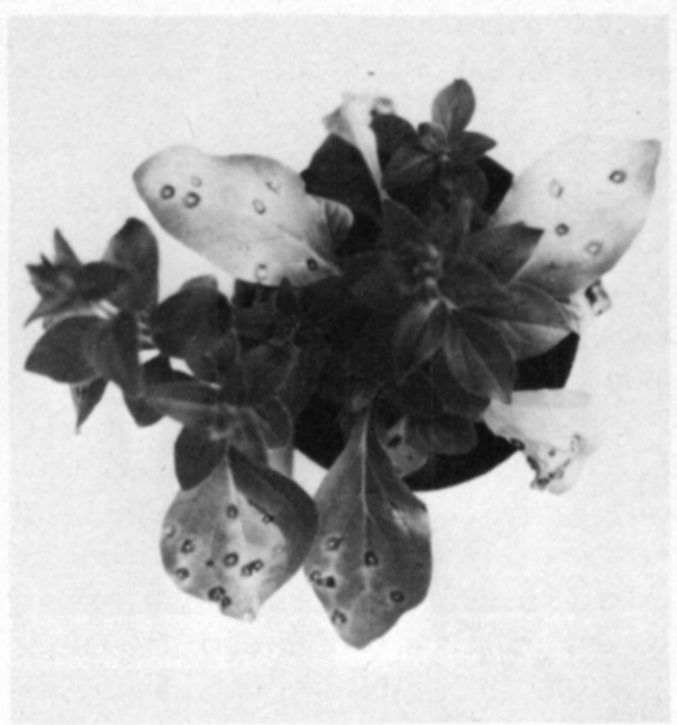

Fig. 7. Tomato black ring virus. Local ring spots in Phlox paniculata.

ever, not determined, so the frequency of occurrence in Finland could be greater than $40 \%$. The frequency of fungal occurrence in

Table 5. Reaction of ornamental plants naturally infected or inoculated with Finnish isolates of soilborne viruses.

\begin{tabular}{|c|c|c|c|c|c|c|c|c|c|c|}
\hline \multirow[t]{3}{*}{ Plant species } & \multicolumn{10}{|c|}{ Reaction' of ornamental plants to soil-borne virus isolates } \\
\hline & \multicolumn{3}{|c|}{$\mathrm{TNV} / \mathrm{Mn} 31$} & \multirow{2}{*}{$\begin{array}{l}\text { TMV/ } \\
\text { Mn } 337 \\
\text { mechan. }\end{array}$} & \multicolumn{2}{|c|}{$\begin{array}{r}\text { TRV/Mn } 159 \\
\text { Mn } 498\end{array}$} & \multicolumn{3}{|c|}{ TBRV/Mn 389} & \multirow{2}{*}{$\begin{array}{l}\text { RRSV/ } \\
\text { Mn } 499 \\
\text { mechan. }\end{array}$} \\
\hline & mechan. & & Olpid. & & mechan. & Trichod. & mechan. & & Longid. & \\
\hline Anemone pulsatilla $\mathrm{L}$. & --- & & -- & --- & L S - - & -- & $\mathrm{L}--$ & - & -- & --- \\
\hline $\begin{array}{l}\text { Aquilegia vulgaris } \mathrm{L} \text {. } \\
\text { Aruncus dioicus }\end{array}$ & --- & & -- & L S - - & $\mathrm{L}(\mathrm{S})-$ & -- & --- & & -- & $\mathrm{L}---$ \\
\hline $\begin{array}{l}\text { (Walt.) Fern. } \\
\text { Astilbe D. Don. }\end{array}$ & --- & & -- & $\mathrm{L}---$ & --- & -- & --- & - & $-\mathbf{R}$ & --- \\
\hline $\begin{array}{l}\text { (A. x aréndsii) } \\
\text { Begonia } \mathrm{L} \text {. }\end{array}$ & & - & $-\mathbf{R}$ & & & & & & $\mathbf{R}$ & \\
\hline $\begin{array}{l}\text { (B. } \mathrm{x} \text { horténsis) } \\
\text { Bergenia } \mathrm{x} \text { schmidtii }\end{array}$ & L S - & - & & $\mathrm{L}---$ & $-\mathrm{S}-$ & -- & --- & - & $-\mathbf{R}$ & --- \\
\hline $\begin{array}{l}\text { (Regel) Silva-Tarouca } \\
\text { Dicentra spectabilis }\end{array}$ & L S - & - & $-\mathbf{R}$ & $\mathrm{L}--$ & --- & -- & --- & & -- & --- \\
\hline $\begin{array}{l}\text { (L.) Lem. } \\
\text { Euphorbia cyparis- }\end{array}$ & & & & L S R - & $-\mathrm{S} R$ & S R & & & & \\
\hline $\begin{array}{l}\text { sias } \mathrm{L} \text {. } \\
\text { Liatris spicata }\end{array}$ & --- & & -- & $\mathrm{L}---$ & $\mathbf{L}--$ & -- & --- & & -- & --- \\
\hline (L.) Willd. & --- & & -- & $\mathrm{L}---$ & $\mathrm{L}--$ & -- & $\mathbf{L}--$ & - & -- & --- \\
\hline $\begin{array}{l}\text { Phlox paniculata } \mathrm{L} \text {. } \\
\text { Primula } \mathrm{x} \text { pubescens }\end{array}$ & L S R & - & S R & - S R - & $-\mathrm{S}$ R & S R & L S R & & S R & --- \\
\hline Jacq. & --- & & -+ & & & S R & --- & & -- & \\
\hline Solidago x hybrida $\mathrm{L}$. & & & & $\mathbf{R}-$ & & $-\mathbf{R}$ & & - & $\mathbf{R}$ & \\
\hline Viola cornuta $\mathrm{L}$. & & & $\mathbf{R}$ & $\mathbf{R}-$ & & $\mathbf{R}$ & & & & \\
\hline $\begin{array}{l}\text { Tagetes erecta } \mathrm{L} \text {. } \\
\text { annual }\end{array}$ & L S & & $\mathbf{R}$ & L S R - & $\mathbf{L}-\mathbf{R}$ & & & & -- & \\
\hline
\end{tabular}

\footnotetext{
See table 4
} 
Swedish nurseries is $50 \%$, (RYDÉN and ERIKSSON 1978) and in Denmark $75 \%$ (JACOBSEN 1943).

Proportional to the samples taken, TNV was isolated most commonly from fine sand and silt, as was the case with RYDÉn and ERIKSSON (1972). According to MAC FARLANE (1968), TNV and its vectors were most common in sandy soils, which are, however, rare in Finnish nurseries.

TNV was common in weeds such as Senecio vulgaris, Stellaria media, Taraxacum officinale and Viola arvensis. It has been isolated from the roots of numerous plants, but caused systemic infection only in quite few plants (KAssanis 1970). Bremer and LAhDENPERÄ
(1980) found TNV, however, later causing heavily systemic infection in out-door cucumbers in Finland.

Tobacco rattle virus (TRV) was isolated most commonly from light soils, confirming what other researchers have found ( $V_{A N}$ HoOF 1970, COOPER 1971 and RYDÉn and ERIKSSON 1978). TRV commonly infected perennials such as Phlox paniculata and Dicentra spectabilis (cf. LiHNELL and NILSSON 1969) and was isolated from certain weeds, for example Stellaria media (cf. COOPER and HARRISON 1973).

The vector of TRV, Trichodorus sp., was isolated from the soil samples of four nurseries and three experimental fields. The

Table 6. Changes in the abundance of Longidorus sp. in untreated, fallowed and chemical treated soil.

Treatments

in $1973-1974$
Mean number of Longidorus $/ 200 \mathrm{~g}$ soil on the

$\begin{array}{llllllll}10.5 .73 & 14.6 .73 & 18.7 .73 & 16.8 .73 & 10.6 .74 & 20.9 .74\end{array}$

Viruses isolated with bait plants in the end of exp.

\section{A. Soil with peren-}

nial plants in 1972

with crop

with crop, peat added

fallowed

fallowed, peat added

D-D-treated'

B. Soil fallowed

in 1972

fallowed onward

weedgrown

$\begin{array}{rcc}7.2 & 3.8 & 1.3 \\ 4.8 & 1.2 & 0 \\ 11.2 & 4.0 & 1.0 \\ 3.7 & 0.4 & 0 \\ 6.7 & 2.3 & 0.6 \\ & & \\ & & \\ 0 & 0 & 0 \\ 6.0 & 2.3 & 0.3\end{array}$

$\begin{array}{ccc}0.7 & & 4.0 \\ 0 & & 1.0 \\ 0.4 & & 0 \\ 0 & & 0 \\ 0.3 & 1 & 0\end{array}$

2.0

0

0.5

0

0

$+-$

' Di-Trapex treatment $500 \mathrm{l} /$ ha the 20. 9.1973 (arrow), rolled.

Table 7. Changes in the abundance of Trichodorus sp. in untreated, fallowed and chemical treated soil.

\begin{tabular}{|c|c|c|c|c|c|c|c|}
\hline \multirow{2}{*}{$\begin{array}{l}\text { Treatments } \\
\text { in } 1973-1974\end{array}$} & \multicolumn{6}{|c|}{ Mean number of Trichodorus $/ 200 \mathrm{~g}$ soil on the } & \multirow{2}{*}{$\begin{array}{l}\text { Viruses isolated } \\
\text { with bait plants } \\
\text { in the end of exp } \\
+-\end{array}$} \\
\hline & 23. 5.73 & 25.6 .73 & 4. 8.73 & 1. 9.73 & 16.6 .74 & 19. 9.74 & \\
\hline with crop ${ }^{1}$ & 31.3 & 2.3 & 10.7 & 30.7 & 32.0 & 1.0 & + \\
\hline with crop, peat added & 23.8 & 7.0 & 1.3 & 28.0 & 15.0 & 1.0 & + \\
\hline fallowed & 23.3 & 2.0 & 10.7 & 29.3 & 14.0 & 0.5 & - \\
\hline fallowed, peat added & 19.0 & 4.7 & 7.6 & 24.0 & 8.0 & 0 & - \\
\hline Potato, untreated & - & - & - & - & 7.0 & 0.5 & + \\
\hline Potato, treated ${ }^{2}$ & - & - & - & - & 3.0 & 0 & - \\
\hline
\end{tabular}

1 10. 6. 73 planted: Anemone pulsatilla, Begonia semperflorens, Liatris spicata, Delphinium cultorum, Amelanchier spicata; Cotoneaster integrima, Crataegus intricata, Potentilla fructicosa, Rosa rugosa

2 Nemagon treatment $0.7 \mathrm{~kg} / \mathrm{ha}$ the 21. 5. 1974 (arrow) 
soaking of nematodes was not, however, performed on all the samples, so it is probable that Trichodorus is also present in other experimental sites where TRV was isolated. It has been found to be quite common in Scandinavian countries (KRISTENSEN and ENGSBRO 1966, BJörnstad and StÖEn 1967).

The relative abundance of tomato black ring virus (TBRV) can be explained by the abundance of Phlox paniculata-samples. The one-sided sampling can be criticized. RYDÉN and ERIKSSON (1978) isolated TBRV only from one nursery sample. RYDÉn (1965) has, on the other hand, isolated TBRV from Phlox plants as SCHMElzer (1963) did before her. The same virus was also isolated from the only Astilbe hybrida-sample, as did SCHMELzer (1963).

The Longidorus-nematodes soaked from four sample sites were not identified by species. Comparison to Scottish (TAYLOR and Murant 1969) and Swedish (Andersson 1974 and ERIKSSON 1975) studies gives cause to assume that the species in question is L.elongatus. Even a single Longidorus-nematode was able to transmit TBRV to young petunia seedlings, as Harrison (1969) had demonstrated with L.attentatus species.

Raspberry ringspot virus (RRSV) could also be isolated from the roots of Phlox paniculata two times, once from Senecio vulgaris and once from red currant, Ribes rubrum cv. Rondom. BREMER (1983) has later isolated RRSV from black currant cv. Sunderbyn and Öjebyn in Finland. VAN Der Meer (1965) has earlier described RRSV as the cause for red currant spoon-leaf. The virus was not transmitted with Longidorus-nematode in this study.

The relatively low occurrence of Longidorus-nematode, and the relative abundance of the virus it transmits in perennials, gives cause for the assumption that viruses as well as nematodes may have been introduced to Finland with vegetatively propagated plant material. In Sweden, the ten nurseries, from where ERIKSSON isolated Longidorus-nematodes (RYDÉn and ERIKSSON 1978), are all situated to the south of Finland.

Although TNV, TMV and TRV were isolated from the roots of inoculated Tagetes erecta, TRV and TBRV could not be isolated from the roots of Tagetes growing on the experimental areas. Tagetes has been found to have nematicidal effect (OOESTENBrink et al. 1957 and Uhlenbroek and Bijloo 1958).

It should also be noted that soil-borne viruses were isolated most commonly from old nurseries, particularly in the immediate vicinity of office buildings and packing rooms. In such areas where perennials were cultivated, fallowing and rotation was practiced less frequently than on other parcels. Because soilborne viruses, especially Nepo- and Tobraviruses, are commonly seedborne in weeds (Lister and Murant 1967), which act as intermediate hosts for nematodes, it is logical to assume that careful fallowing diminishes their occurrence (COOPER and HARRISON 1973, HANADA and Harrison 1977).

\section{References}

ANDERSSON, S. 1974. Skador av Longidorus elongatus i jordgubbar. Văxtskyddsnotiser 38: 14-18.

Babos, P. and Kassanis, B. 1963 Serological relationship and some properties of tobacco necrosis virus strains. J. Gen. Microbiol. 32: 135-144.

Bjernstad, A. and Støen, M. 1967. Rattlevirus med Trichodorus pachydermus som vektor. Norsk Landbruk 167/8: 1-8.
Bremer, K. and Lahdenperä, M-L. 1980. A disease of out-door cucumbers by the tobacco necrosis virus in Finland. Ann. Agric. Fenn. 19: 5-8.

Bremer, K. 1983. Viral diseases occuring in Ribes species in Finland Ann. Agric. Fenn. 22: 104-109.

COOPER, J.I. 1971. The distribution in Scotland of tobacco rattle virus and its nematode vectors in relation to soil type. Pl. Path. 20: 51-58. 
Cooper, J.I. and Thomas, P.R. 1971. Chemical treatment of soil to prevent transmission of tobacco rattle virus to potatoes by Trichodorus spp. Ann. Appl. Biol. 69: 23-34.

EngsBro, B. 1973. Undersögelser og forsög vedrörende jordbårne vira. I Rattlevirus, fortsatte undersögelser i kartoffler. Tidsskr. Pl.avl 77: 103-117.

ERIKSSON, B. 1974. Virusspridande nematoder. Växtskyddsnotiser 38 : 43-51.

Hanada, K. and Harrison, B. 1977. Effects of virus genotype and temperature on seed transmission of nepoviruses. Ann. Appl. Biol. 85: 79-92.

Harrison, B. 1969. On the transmission of tomato black ring virus by Longidorus attenuatus (Nematoda). Zentbl. ParasitKde 123: 226-229.

Hoof, VAN H.A. 1970. Some observations on retention of tobacco rattle virus in nematodes. Neth. J. Pl. Path. 76: 329-330.

JaCOBSEn, B. 1943. Studies on Olpidium brassicae (Wor.) Dang. Contr. Dep. Pl. Path. R. Vet. Agric. Coll., Copenhagen 24: 1-53.

Kassanis, B. 1970. Tobacco necrosis virus. CMI Descr. Pl. Vir. No. 14.

Kristensen, H.R. and EnGSBRo, B. 1966. Undersögerlser og försög vedrörende jordbårne vira. I Rattle-virus. Tidsskr. Pl.avl 70: 353-379.

Lihnelt, D. and Nilsson, B. 1969. Vorkommen von Tabakrattle-Virus on Dicentra spectabilis in Schweden. Phytopath. Z. 65: 1-6.

Lister, R.M. and MUrant, A.F. 1967. Seed-transmission of nematode-borne viruses. Ann. Appl. Biol. 59: 4962.

Macfarlane, I. 1968. Transmission of tobacco necrosis virus to higher plants by Olpidium - a model for the activities of lower fungi parasitic in algae. Veröff.

\section{SELOSTUS}

\section{Maalevintäisten virusten esiintyminen Suomen taimitarhoissa ja eräillä koekentillä}

\section{Eeva Tapio \\ Helsingin yliopiston kasvipatologian laitos, 00710 Helsinki}

Maalevintăisten virusten esiintymistă 30 suomalaisessa taimitarhassa ja kolmen tutkimusaseman puutarhakoekentällä selvitettiin 1970-luvun alussa. Kerätyistă 672 kasvi- ja maanäytteestă eristettiin 161:stä eli $26.9 \%$ :sta viruksia. Yleisimmin esiintyi tupakan nekroosivirusta (TNV) ja tupakan rattlevirusta (TRV), joita oli $42.5 \%$
Inst.-f.-Meeresforsch.-in Bremenhaven.-Sonderdr. 1968 Bd. 3: 133-148.

Murant, A.F. and Taylor, C.E. 1965. Treatment of soil with chemicals to prevent transmission of tomato black ring and raspberry ring spot viruses by Longidorus elongatus (de Man). Ann. Appl. Biol. 55: 227-237.

OoestenbrinK, M., Kuiper, K. and S'Jacob, J.J. 1957. Tagetes als Fiendpflansen von Pratylenchus-Arten. Nematologica Suppl. 2: 424S-433S.

RydéN, K. 1965. Phlox ringfläck - en svår sjukdom orsakad av tomat-svartringvirus. Växtskyddsnotiser 29: $77-81$.

RYdén, K. and ERIKSSON, B. 1978. Jordburna virus och deras vektorer i svenska plantskolor. Växtskyddsrapporter, Trädgård 3. Swed. Univ. Agric. Sci, Uppsala 1978.

Schmelzer, K. 1963. Untersuchungen an Viren der Zierund Wildgehölze. 4. Mitteilung. Versuche zur Differenzierung und Identififerung der Ringfleckenviren. Phytopath. Z. 46: 315-342.

TAPIO, E. 1972. The appearance of soil-borne viruses in Finnish plant nurseries. Maatal. tiet. Aikak. 44: 83-92.

- 1976. Taimitarhojen maalevintäiset virukset. Koetoim. ja Käyt. 33: 17-20.

Uhlenbroek, J.H. and Busoo, J.D. 1958. Isolation and structure of a nematicidal principle occuring in Tagetes roots. Proc.IV Int. Cong. Crop Protect. Hamburg, 1957: 579-581.

VAN Der MeER, F.A. 1965. Investigations of currant viruses in the Netherlands. II. Futher observations on spoon leaf virus, a soil-borne virus transmitted by the nematode Longidorus elongatus. Neth. J. Plant. Path. 71: 33 .

Ms received April 1, 1985 ja $23.7 \%$ virusisolaateista. Tomaatin mustalaikkuvirus (TBRV) ja vadelman rengaslaikkuvirus (RRSV) eristettiin ensi kertaa Suomessa. TBRV'n runsas esiintyminen 32 năytteessă johtuu lăhinnă syysleimunăytteiden (Phlox paniculata L.) runsaudesta. RRSV eristettiin vain muutamasta năytteestă. Kaikkien edellă mainittujen virusten 
vektoreita tavattiin useissa maa- ja juurinäytteissä. TNV'n sienivektoria Olpidium brassicae (Wor.) Dang. tutkittiin juuria mikroskopoimalla. Vektoriankeroisia, TRV'tă siirtăviä Trichodorus sp. - sekä TBRV'tă ja RRSV'tă siirtăviă Longidorus sp.-ankeroisia eristettiin maanäytteistă huuhtomalla. Edellă mainittujen virusten lisăksi mäăritettiin kuuden taimitarhan ja kahden koekentän 31 näytteestå tupakan mosaiikkivirus (TMV), jonka vektoria ei tunneta.

Viruksia eristettiin monista rikkakasvinăytteistă, eri- tyisen runsaasti pihatăhtimön (Stellaria media (L.)Vill.) ja peltovillakon (Senecio vulgaris L.) juurista. Monivuotiset ryhmăkasvit olivat yleisesti viroottisia. Syysleimuista eristettiin kaikkia edellă mainittuja viruksia, useimmiten TBRV ja TRV. TBRV tavattiin myös jaloangervossa Astilbe $\mathrm{x}$ arendsii). Särkynytsydän (Dicentra spectabilis (L.) Lem.) oli kuten syysleimukin yleisesti TRV'n infektoima. Torjuntakokeista ei saatu selkeitả tuloksia. Huolellisen kesannoinnin todettiin kuitenkin selvästi văhentävän virusten ja niiden vektoreiden esiintymistä. 